ISSN 1678-3921

Journal homepage: www.embrapa.br/pab

For manuscript submission and journal contents, access: www.scielo.br/pab

\title{
Agronomic performance of cowpea genotypes in southwestern Brazilian Amazon
}

\begin{abstract}
The objective of this work was to evaluate the agronomic performance of cowpea (Vigna unguiculata) genotypes over three crop years, in the ecosystem of Rio Branco, in the state of Acre, Brazil. The experiments were carried out in the 2016, 2017, and 2018 crop seasons, in a randomized complete block design, with four replicates. Eight agronomic traits were evaluated in 14 cowpea genotypes, which included: 12 lines (BDO 1-5-11, BDO 1-5-15, BDO 1-5-19, BDO 1-5-24, PDO 1-5-26, PDO 1-5-4, PDO 1-5-5, PDO 1-5-7, PDO 1-5-8, PDO 1-5-10, PDO 1-5-11, and PDO 1-5-14) and two cultivars (BRS Tumucumaque and BRS Imponente). A significant difference was observed in the genotype $\mathrm{x}$ crop year interaction, for most traits. Although there was no statistical difference between genotypes in the studied crop years, dry seed productivity was higher than the national average. All cowpea lines and cultivars from the genetic breeding program show equivalent and favorable agronomic performances in the environmental conditions of Rio Branco. Therefore, these genotypes can be selected for incorporation into the production system of Rio Branco.
\end{abstract}

Index terms: Vigna unguiculata, breeding, BRS Imponente, BRS Tumucumaque, family farming.

\section{Desempenho agronômico de genótipos de feijão-caupi no sudoeste da Amazônia brasileira}

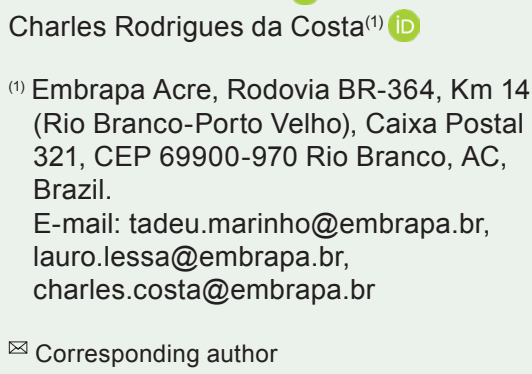

Resumo - O objetivo deste trabalho foi avaliar o desempenho agronômico de genótipos de feijão-caupi (Vigna unguiculata) em três anos agrícolas, no ecossistema de Rio Branco, no estado do Acre, Brasil. Os experimentos foram conduzidos nos anos agrícolas de 2016, 2017 e 2018, em delineamento de blocos ao acaso, com quatro repetições. Foram avaliados oito caracteres agronômicos, em 14 genótipos de feijão-caupi, que incluíram: 12 linhagens (BDO 1-5-11, BDO 1-5-15, BDO 1-5-19, BDO 1-5-24, PDO 1-5-26, PDO 1-5-4, PDO 1-5-5, PDO 1-5-7, PDO 1-5-8, PDO 1-5-10, PDO 1-5-11 e PDO 1-5-14) e duas cultivares (BRS Tumucumaque e BRS Imponente). Observouse diferença significativa na interação genótipo $\mathrm{x}$ safra, para a maioria das características. Embora não tenha havido diferença estatística entre os genótipos nas safras estudadas, a produtividade de grãos secos foi superior à da média nacional. Todas as linhagens e as cultivares de feijão-caupi do programa de melhoramento genético apresentam desempenho agronômico equivalente e favorável nas condições ambientais de Rio Branco. Portanto, esses genótipos podem ser selecionados para incorporação ao sistema produtivo de Rio Branco.

Termos para indexação: Vigna unguiculata, melhoramento, BRS Imponente, BRS Tumucumaque, agricultura familiar. 


\section{Introduction}

Cowpea [Vigna unguiculata (L.) Walp.] is one of the most important sources of human food in tropical and subtropical regions of the world (Lopes et al., 2018). In Brazil, cowpea is marketed as both immature and dry grains, "acarajé" flour, and seed (Silva et al., 2018).

The world planted area is approximately 12.6 million hectares, and Nigeria ranks as the largest producer, with 3.4 million metric tons (FAO, 2019). In Brazil, the area planted in the 2019/2020 agricultural year, was 1.3 million ha, and the average yield was $545 \mathrm{~kg} \mathrm{ha}^{-1}$ (Acompanhamento..., 2020).

In the Northern and Northeastern Brazil, cowpea is still grown as a secondary crop (Medeiros et al., 2017) mainly by small farmers. However, the easiness of adaptation to different Brazilian ecosystems has allowed the crop to spread to other regions, notably the Midwest (Freire Filho, 2011).

In Acre state, cowpea is an important source of income for traditional populations and family farmers (Mendonça et al., 2018). The crop is locally known as "feijão-de-corda" (string bean) or "feijão-depraia" (beach bean) because of the cultivation in the floodplains of the state's rivers. The crop, also known as the "dry-season bean", is planted during the dry season or the Amazonian summer (between May and October). According to some authors (Oliveira et al., 2015; Mendonça et al., 2018), cowpea, together with common bean, makes up the main source of income and protein available throughout the year for a great variety of communities.

Although cowpea is an important crop for human food in various ways, its productive potential is little explored. According to Valeriano et al. (2019), cowpea is a subsistence crop and still lacks research on the management and recommendation of cultivars. Dutra et al. (2012) point out that the average Brazilian yield does not reflect this crop potential. The main reasons for the low cowpea yield are the lack of knowledge on the genotype $\mathrm{x}$ environment interactions and traditional cultivars with low yield capacity (Públio Júnior et al., 2017; Silva et al., 2018).

In view of this scenario, some universities and research centers have developed several genetic breeding programs, mainly the Embrapa's cowpea breeding program. As result, there was the launch and recommendation of several cultivars adapted to the most varied edaphoclimatic conditions in Brazil, such as cowpea BRS Tumucumaque and BRS Imponente that stood out among crops in some Brazilian states (Cavalcante et al., 2014; Rocha et al., 2017).

According to Teixeira et al. (2010), the correct cultivar selection for a given environment and production system is crucial for achieving good yields. However, it is not sufficient to achieve success with the crop. Aspects related to cycle, plant architecture, seed quality, and resistance to diseases are highly relevant. Públio Júnior et al. (2017) emphasize that cowpea cultivars respond differently to the soil and climate conditions of the production regions. Therefore, preliminary studies aiming to evaluate the yield potential of new genotypes derived from breeding programs are essential for the recommendation of new cultivars.

In the state of Acre, the cultivars used by farmers are creole-based and mixed with seed provided by the government since a long time ago (Mendonça et al., 2018). Thus, due to the importance of cowpea crop in the state, studies are required to introduce, evaluate, and select genotypes that combine adaptation to the local ecosystem and high yields, besides taking into account the demands of consumers.

The objective of this work was to evaluate the agronomic performance of cowpea genotypes over three crop years, in the ecosystem of Rio Branco, in the state of Acre, Brazil.

\section{Materials and Methods}

The experiments were installed, conducted, and evaluated between April and July in three crop years (2016,2017, and2018), in theEmbrapa Acre experimental field, in the municipality of Rio Branco, in the state of Acre, Brazil, located at 9 $9^{\circ} 58^{\prime} 29^{\prime \prime} \mathrm{S}, 67^{\circ} 49^{\prime} 44^{\prime \prime} \mathrm{W}$, at $160 \mathrm{~m}$ altitude. The predominant climate in the region is the Awi type (tropical hot and humid), according to the Köppen-Geiger's classification, with $31^{\circ} \mathrm{C}$ and $21^{\circ} \mathrm{C}$ average maximum and minimum temperatures, respectively, 1,700 $\mathrm{mm}$ accumulated annual rainfall, and $83 \%$ relative humidity. Data on rainfall and average maximum and minimum temperatures for 2016, 2017, and 2018 are presented in Figure 1.

The soil of the experimental area was classified as a Argissolo Vermelho distrófico típico, mediumclay texture, according to Brazilian soil classification system (Santos et al., 2018). The soil chemical 
properties in the $0.0-0.2 \mathrm{~m}$ layer were: $\mathrm{P}_{\text {resin }}, 23.57 \mathrm{mg}$ $\mathrm{dm}^{-3} ; \mathrm{P}_{\text {Mehlich-1 }}, 6.10 \mathrm{mg} \mathrm{dm}^{-3} ; \mathrm{pH}, 6.18 ; \mathrm{H}+\mathrm{Al}, 2.71 \mathrm{cmol}_{\mathrm{c}}$ $\mathrm{dm}^{-3}$; Ca, $2.81 \mathrm{cmol}_{\mathrm{c}} \mathrm{dm}^{-3} ; \mathrm{Mg}, 0.93 \mathrm{cmol}_{\mathrm{c}} \mathrm{dm}^{-3} ; \mathrm{K}, 0.37$ $\mathrm{cmol}_{\mathrm{c}} \mathrm{dm}^{-3}$; CEC, $6.82 \mathrm{cmol}_{\mathrm{c}} \mathrm{dm}^{-3}$; sum of bases (SB), $4.11 \mathrm{cmol}_{\mathrm{c}} \mathrm{dm}^{-3} ; \mathrm{C}_{\text {org }}, 9.64 \mathrm{~g} \mathrm{~kg}^{-1} ; \mathrm{OM}, 16.58 \mathrm{~g} \mathrm{~kg}^{-1}$; and base saturation $(\mathrm{V}), 60.26 \%$.

Soil preparation followed the recommendations for conventional planting, consisting of one plowing and two harrowing operations to field level. Soil correction and fertilization were based on soil analysis according to Melo \& Cardoso (2017).

The experiments were carried out between April and July of the three crop years, with 14 cowpea genotypes that consisted of 12 lines (BDO 1-5-11, BDO 1-5-15, BDO 1-5-19, BDO 1-5-24, PDO 1-5-26, PDO 1-5-4, PDO 1-5-5, PDO 1-5-7, PDO 1-5-8, PDO 1-5-10, PDO 1-5-11, and PDO 1-5-14), and two cultivars (BRS Tumucumaque and BRS Imponente), belonging to the commercial subclasses evergreen, "canapu", mulatto, smooth white, and rough white, from the genetic breeding program of Embrapa Meio-Norte. The lines BDO ("Bico-de-Ouro") and PDO ("Pingo-de-Ouro"), are individual selections of plants with progeny test from plants collected in the states of Mato Grosso and Piauí (in the semiarid region), respectively.

The experiments in each crop year were arranged in a randomized complete block design with four replicates. The size of plots of each genotype was $2.0 \times 5.0 \mathrm{~m}$. Planting was carried out in $0.50 \mathrm{~m}$ spacing between rows, with 10 seed per linear meter, reaching 160,000 plants ha $^{-1}$ population. The two central rows of each plot were considered as net plot for data collection.

The following traits were evaluated: seed number per pod (NSP); seed weight per pod (SWP, g); 100seed weight (HSW, g); seed index (SID, \%); dry seed yield (DSY, $\mathrm{kg} \mathrm{ha}^{-1}$ ); plant growth habit (PGH), according to the score ranking as 1 - erect, 2 - semierect, 3 - semiprostrate, and 4 - prostrate; cultivation value $(\mathrm{CV})$, according to the score ranking as $1-$ line/ cultivar without characteristics suitable for commercial cultivation, 2 - line/cultivar with few characteristics suitable for commercial cultivation, 3 - line/cultivar with good deal of the characteristics suitable for commercial cultivation, 4 - line/cultivar with most characteristics suitable for commercial cultivation, and 5 - line/cultivar with almost all characteristics suitable

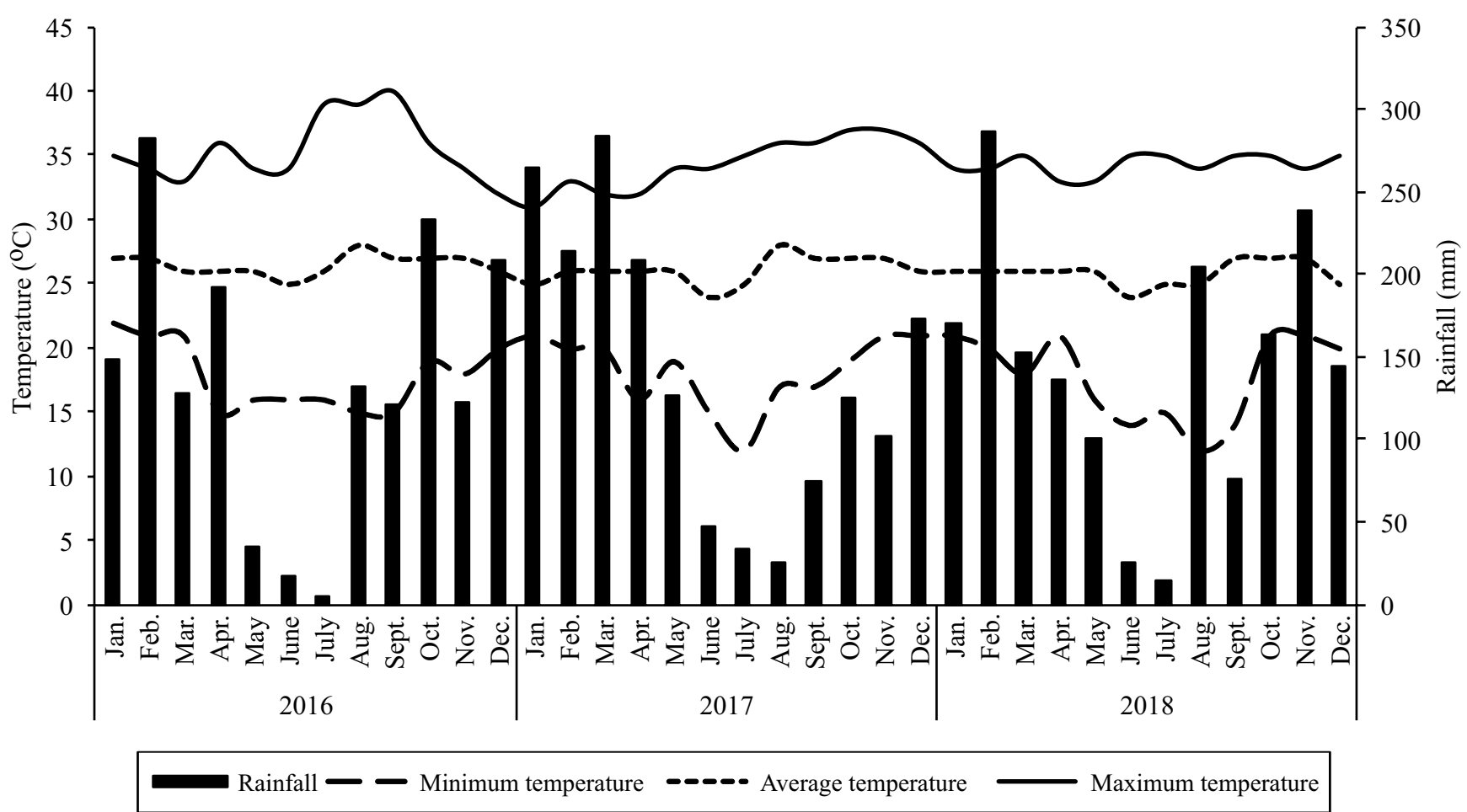

Figure 1. Rainfall and maximum, average, and minimum temperatures, in the municipality of Rio Branco, in the state of Acre, Brazil, in the 2016, 2017, and 2018 crop years (Agritempo, 2020). 
for commercial cultivation; and lodging (LOD), according to the score ranking as 1 - no lodged plant or main branch unbroken, $2-1 \%$ to $5 \%$ lodged plants or main branch broken, $3-6 \%$ to $10 \%$ lodged plants or main branch broken, $4-11 \%$ to $20 \%$ lodged plants or main branch broken, and 5 - above $20 \%$ lodged plants or main branch broken. The score ranking for the trait plant growth habit, cultivation value, and lodging were based on scoring tables described and used by Embrapa Meio-Norte, in the breeding and selection of genotypes according to Silva et al. (2018).

Data were analyzed by the joint analysis of variance for experiments of equal size with the data at the plot level, considering the crop year as a different environment, using the statistical program Sisvar (Ferreira, 2014), as recommended by Banzatto \& Kronka (2006). The means of genotypes were compared by the Scott-Knott's test, and the means of years by the Tukey's test, at 5\% probability each. In order to meet the assumptions of the analysis of variance, the data were subjected to transformation using the equations $(\mathrm{x}+1)^{0.5}$ for the variable NSP, and $(\mathrm{x})^{0.5}$ for PGH, CV, and LOD. Unfolding of the significant genotype $\mathrm{x}$ year interactions were carried out.

\section{Results and Discussion}

The joint analysis of variance showed that the effect of genotype $(G) x$ crop year $(Y)$ interaction was significant for NSP, SWP, DSY, PGH, CV, and LOD (Table 1). The variable HSW showed a significant effect only among genotypes. A significant difference was also observed among crop years for most yield traits (NSP, SWP, and DSY). Seed index showed no difference in the $G \times Y$ interaction nor in isolated factors. Sousa et al. (2015) evaluated different cowpea genotypes in two environments and found significant differences for most of the yield traits, in relation to the tested environments. The difference among crop years observed in this work indicates that there were variations in the crop years evaluated, notably the rainfall distribution (Figure 1), since the experiments were not irrigated, aiming to replicate the cropping system of local farmers who depend entirely on rain water for their farming.

The coefficients of variation ranged from $6.94 \%$ (NSP) to $19.38 \%$ (LOD) and are consistent with the findings in the literature (Teixeira et al., 2010; Locatelli et al., 2014; Pinto et al., 2017; Camara et al., 2018; Silva et al., 2018; Souza et al., 2018).

The analysis of the genotype performance in the crop years for NSP (Table 2), a component of yield in cowpea, showed that two groups were formed in 2016, in which the BDO 1-5-11, BDO 1-5-15, BDO 1-5-19, BDO 1-5-24, PDO 1-5-7, PDO 1-5-8, PDO 1-5-10, and PDO 1-5-14 lines were superior. In 2017, only PDO15-26 was superior to the others. In 2018, most of the genotypes showed no difference for NSP, except for the genotypes PDO 1-5-14 and 'BRS Imponente' that formed the group of the least productive genotypes (Table 2). The fact that the crop year was present in different groups may be related to the variation of the rainfall regime that occurred during the period of experimental conduction in the crop years studied (Figure 1). According to Lopes et al. (2011) and Valeriano et al. (2019), this trait is greatly affected by climatic variations, mainly water deficiency. Rainfall levels ranging among 250 and $500 \mathrm{~mm}$ are suitable for the cultivation of cowpea (Andrade Júnior et al., 2017).

Teixeira et al. (2010) and Públio Júnior et al. (2017) recorded means ranging from 10 to 11 seed per pod, which is in good agreement with the means found in the present study.

The BDO 1-5-15, BDO 1-5-19, BDO 1-5-24, PDO 1-5-4, PDO 1-5-7, and PDO 1-5-11 lines, and BRS Tumucumaque and BRS Imponente cultivars did not differ in relation to the crop year, showing, thus, a tendency to stabilization (Table 2). Therefore, the stabilization of genotypes for NSP is essential, as it is directly related to the crop yield.

The SWP is a trait evaluated in cowpea trials (Torres et al., 2015), but no difference was found among genotypes for each crop year, in the present work (Table 3). The BDO 1-5-15, BDO 1-5-19, BDO 1-5-24, PDO 1-5-26, PDO 1-5-4, PDO 1-5-7, and PDO 1-5-11 lines, as well as BRS Tumucumaque and BRS Imponente cultivars did not differ for the different crop years, showing stability for SWP in the conditions of the present study. The stabilization of this trait together with the number of seed per plant has a great significance, as they directly influence production.

The lack of a significant interaction in HSW indicates that the genotypes kept the same ranking order over the three crop years (Table 3). However, when compared with the general mean of the genotypes, BRS Imponente cultivar showed the highest HSW. No 
significant difference was found among crop years. We point out, however, that all lines showed averages statistically equal to those of BRS Tumucumaque cultivar. As stated by Locatelli et al. (2014), this trait has a greater resistance to changes induced by environmental conditions, which suggests that the variation among genotypes found in the present study are probably derived from genotype.

Although no difference was found among the genotypes for DSY, in the crop years (Table 4), the means of this trait varied from $975 \mathrm{~kg} \mathrm{ha}^{-1}$ (PDO 1-511) to $1,523 \mathrm{~kg} \mathrm{ha}^{-1}$ (PDO 1-5-26), from $720 \mathrm{~kg} \mathrm{ha}^{-1}$ ('BRS Tumucumaque') to $1,357 \mathrm{~kg} \mathrm{ha}^{-1}$ (BDO 1-5-15), and from $1,093 \mathrm{~kg} \mathrm{ha}^{-1}$ (PDO 1-5-8) to $1,164 \mathrm{~kg} \mathrm{ha}^{-1}$ (PDO 1-5-7) in 2016, 2017, and 2018, respectively. The BDO 1-5-11, BDO 1-5-15, BDO 1-5-19, BDO 1-5-24, PDO 1-5-4, PDO 1-5-5, PDO 1-5-10, PDO 1-511, and PDO 1-5-14 lines, and the BRS Imponente cultivar show stability for the trait seed yield, since no significant difference was found among crop years.

Table 1. Analysis of variance of traits, plant growth habit, cultivation value and lodging of 14 cowpea (Vigna unguiculata) genotypes, in the municipality of Rio Branco, in the state of Acre, Brazil, in the 2016, 2017, and 2018 crop years ${ }^{(1)}$.

\begin{tabular}{|c|c|c|c|c|c|c|c|c|c|}
\hline \multirow{2}{*}{$\begin{array}{l}\text { Source of } \\
\text { Variation }\end{array}$} & \multirow[t]{2}{*}{$\mathrm{DF}^{(2)}$} & \multicolumn{8}{|c|}{ Mean square $^{(3)}$} \\
\hline & & NSP & $\begin{array}{l}\text { SWP } \\
(\mathrm{g})\end{array}$ & $\begin{array}{l}\mathrm{HSW} \\
(\mathrm{g})\end{array}$ & $\begin{array}{l}\text { SID } \\
(\%)\end{array}$ & $\begin{array}{c}\text { DSY } \\
\left(\mathrm{kg} \mathrm{ha}^{-1}\right)\end{array}$ & PGH & $\mathrm{CV}$ & LOD \\
\hline Block (year) & 9 & $2.43^{\text {ns }}$ & $0.11^{\mathrm{ns}}$ & $2.80^{\mathrm{ns}}$ & $104.91^{\mathrm{ns}}$ & $98023.55^{* *}$ & $0.45^{\text {ns }}$ & $1.030^{*}$ & $1.34 *$ \\
\hline Year $(Y)$ & 2 & $58.21^{* *}$ & $2.96 * *$ & $2.52^{\mathrm{ns}}$ & $88.63^{\mathrm{ns}}$ & $451366.46^{* *}$ & $0.05^{\mathrm{ns}}$ & $0.005^{\mathrm{ns}}$ & $1.16^{\mathrm{ns}}$ \\
\hline Genotype (G) & 13 & $15.43^{* *}$ & $0.20 *$ & $153.79^{* *}$ & $80.67^{\mathrm{ns}}$ & $72333.13^{* *}$ & $1.60 * *$ & $1.544^{* *}$ & $1.31^{* *}$ \\
\hline $\mathrm{G} \times \mathrm{Y}$ & 26 & $4.58^{*}$ & $0.17^{*}$ & $7.71^{\mathrm{ns}}$ & $113.37^{\mathrm{ns}}$ & $56601.90 * *$ & $0.75^{*}$ & $1.422^{* *}$ & $1.17 * *$ \\
\hline Error & 112 & 2.49 & 0.09 & 6.71 & 74.48 & 29027.52 & 0.46 & 0.438 & 0.55 \\
\hline $\begin{array}{l}\text { Coefficient of } \\
\text { variation (\%) }\end{array}$ & & 6.94 & 13.78 & 11.84 & 10.95 & 14.33 & 18.81 & 11.13 & 19.38 \\
\hline Overall mean & & 10.63 & 2.26 & 21.88 & 78.83 & 1188.68 & 1.92 & 3.08 & 1.93 \\
\hline
\end{tabular}

(1)*, **Significant at $5 \%$ and $1 \%$, respectively, by the F-test. ${ }^{(2)} \mathrm{DF}$, degree of freedom. ${ }^{(3)}$ Mean square for: NSP, number of seed per pod; SWP, seed weight per pod; HSW, 100-seed weight; SID, seed index; DSY, dry seed yield; PGH, plant growth habit; CV, cultivation value; and LOD, lodging. ${ }^{\mathrm{n}}$ Nonsignificant.

Table 2. Means of number of seed per pod of 14 cowpea (Vigna unguiculata) genotypes, in the 2016, 2017, and 2018 crop years, in the municipality of Rio Branco, in the state of Acre, Brazil ${ }^{(1)}$.

\begin{tabular}{lccc}
\hline Genotype $^{(2)}$ & \multicolumn{3}{c}{ Number of seed per pod } \\
\cline { 2 - 4 } & 2016 & 2017 & $10.35 \mathrm{bB}$ \\
\hline BDO 1-5-11 & $13.25 \mathrm{aA}$ & $11.00 \mathrm{bA}$ & $10.25 \mathrm{aB}$ \\
BDO 1-5-15 & $12.60 \mathrm{aA}$ & $10.30 \mathrm{bA} \mathrm{aA}$ & $10.42 \mathrm{aA}$ \\
BDO 1-5-19 & $12.60 \mathrm{aA}$ & $9.85 \mathrm{cA}$ & $10.12 \mathrm{aA}$ \\
BDO 1-5-24 & $12.00 \mathrm{aA}$ & $13.80 \mathrm{aA}$ & $10.35 \mathrm{aB}$ \\
PDO 1-5-26 & $10.70 \mathrm{bB}$ & $10.75 \mathrm{bA}$ & $10.20 \mathrm{aA}$ \\
PDO 1-5-4 & $11.20 \mathrm{bA}$ & $10.50 \mathrm{bB}$ & $10.32 \mathrm{aB}$ \\
PDO 1-5-5 & $13.95 \mathrm{aA}$ & $10.90 \mathrm{bA}$ & $10.15 \mathrm{aA}$ \\
PDO 1-5-7 & $11.75 \mathrm{aA}$ & $9.10 \mathrm{cB}$ & $11.25 \mathrm{aAB}$ \\
PDO 1-5-8 & $13.40 \mathrm{aA}$ & $10.50 \mathrm{bAB}$ & $9.70 \mathrm{aB}$ \\
PDO 1-5-10 & $12.86 \mathrm{aA}$ & $11.30 \mathrm{bA}$ & $11.10 \mathrm{aA}$ \\
PDO 1-5-11 & $12.80 \mathrm{aA}$ & $10.10 \mathrm{bAB}$ & $8.15 \mathrm{bB}$ \\
PDO 1-5-14 & $11.75 \mathrm{aA}$ & $8.05 \mathrm{cA}$ & $10.20 \mathrm{aA}$ \\
BRS Tumucumaque & $9.65 \mathrm{bA}$ & $6.15 \mathrm{dA}$ & $7.05 \mathrm{bA}$ \\
BRS Imponente & $8.80 \mathrm{bA}$ & 10.63 & \\
\hline Overall mean & &
\end{tabular}

${ }^{(1)}$ Means followed by equal letters, uppercases in the rows, and lowercases in the columns, do not differ by the Tukey's and the Scott-Knott's tests, at $5 \%$ probability each. (2)BDO, "Bico-de-Ouro" lines; PDO, "Pingo-de-Ouro" lines; and BRS Tumucumaque and BRS Imponente cultivars. 
It is noteworthy that the overall mean of dry seed yield recorded in the present study $\left(1,188 \mathrm{~kg} \mathrm{ha}^{-1}\right)$ is higher than the national average yield of $545 \mathrm{~kg} \mathrm{ha}^{-1}$ (Acompanhamento..., 2020), which suggests the good productive capacity of the genotypes evaluated, mainly that of the studied lines.
Means of dry seed yields as those obtained in the present work have been reported in other studies (Silva et al., 2016; Souza et al., 2018; Araújo et al., 2019). According to Matos Filho et al. (2009), differences for yield in the same genotype, across different environments, can occur because of biotic factors and

Table 3. Means of seed weight per pod and 100-seed weight of 14 cowpea (Vigna unguiculata) genotypes, in the 2016, 2017, and 2018 crop years, in the municipality of Rio Branco, in the state of Acre, Brazil ${ }^{(1)}$.

\begin{tabular}{|c|c|c|c|c|c|c|c|}
\hline \multirow[t]{2}{*}{ Genotype $^{(2)}$} & \multicolumn{3}{|c|}{ Seed weight per pod $(\mathrm{g})$} & \multicolumn{3}{|c|}{100 -seed weight $(\mathrm{g})$} & \multirow[t]{2}{*}{ Mean } \\
\hline & 2016 & 2017 & 2018 & 2016 & 2017 & 2018 & \\
\hline BDO 1-5-11 & $2.68 \mathrm{aA}$ & $2.12 \mathrm{aB}$ & $2.19 \mathrm{aAB}$ & 20.25 & 20.50 & 21.37 & $20.70 \mathrm{~b}$ \\
\hline BDO 1-5-15 & $2.56 \mathrm{aA}$ & $2.39 \mathrm{aA}$ & $2.09 \mathrm{aA}$ & 20.87 & 26.75 & 20.87 & $22.83 b$ \\
\hline BDO 1-5-19 & $2.56 \mathrm{aA}$ & $2.17 \mathrm{aA}$ & $2.13 \mathrm{aA}$ & 20.37 & 21.12 & 20.43 & $20.64 b$ \\
\hline BDO 1-5-24 & $2.41 \mathrm{aA}$ & $1.91 \mathrm{aA}$ & $2.11 \mathrm{aA}$ & 20.12 & 19.62 & 20.81 & $20.18 b$ \\
\hline PDO 1-5-26 & $2.31 \mathrm{aA}$ & $2.66 \mathrm{aA}$ & $2.16 \mathrm{aA}$ & 23.62 & 19.25 & 20.93 & $21.27 \mathrm{~b}$ \\
\hline PDO 1-5-4 & $2.53 \mathrm{aA}$ & $2.23 \mathrm{aA}$ & $2.11 \mathrm{aA}$ & 22.83 & 20.75 & 20.68 & $21.29 \mathrm{~b}$ \\
\hline PDO 1-5-5 & $2.97 \mathrm{aA}$ & $2.05 \mathrm{aB}$ & $2.13 \mathrm{aB}$ & 21.25 & 19.75 & 20.68 & $20.56 \mathrm{~b}$ \\
\hline PDO 1-5-7 & $2.56 \mathrm{aA}$ & $2.24 \mathrm{aA}$ & $2.07 \mathrm{aA}$ & 21.75 & 20.62 & 20.37 & $20.91 b$ \\
\hline PDO 1-5-8 & $2.66 \mathrm{aA}$ & $1.80 \mathrm{aB}$ & $2.22 \mathrm{aAB}$ & 20.37 & 19.75 & 19.75 & $19.95 \mathrm{~b}$ \\
\hline PDO 1-5-10 & $2.81 \mathrm{aA}$ & $2.29 \mathrm{aAB}$ & $2.01 \mathrm{aB}$ & 21.83 & 21.75 & 20.70 & $21.39 b$ \\
\hline PDO 1-5-11 & $2.50 \mathrm{aA}$ & $2.29 \mathrm{aA}$ & $2.18 \mathrm{aA}$ & 19.50 & 20.37 & 19.62 & $19.94 \mathrm{~b}$ \\
\hline PDO 1-5-14 & $2.54 \mathrm{aA}$ & $2.25 \mathrm{aA}$ & $1.71 \mathrm{aB}$ & 21.62 & 22.37 & 21.01 & $21.67 \mathrm{~b}$ \\
\hline BRS Tumucumaque & $1.99 \mathrm{aA}$ & $1.61 \mathrm{aA}$ & $2.09 \mathrm{aA}$ & 20.62 & 20.00 & 20.63 & $20.42 \mathrm{~b}$ \\
\hline BRS Imponente & $2.58 \mathrm{aA}$ & $2.17 \mathrm{aA}$ & $2.47 \mathrm{aA}$ & 31.50 & 35.50 & 35.10 & $34.03 \mathrm{a}$ \\
\hline Overall mean & & - & - & $22.01 \mathrm{~A}$ & $22.00 \mathrm{~A}$ & $21.64 \mathrm{~A}$ & - \\
\hline
\end{tabular}

(1) Means followed by equal letters, uppercases in the rows and lowercases in the columns, do not differ by the Tukey's and the Scott-Knott's tests, at $5 \%$ probability each. (2)BDO, "Bico-de-Ouro" lines; PDO, "Pingo-de-Ouro" lines; and BRS Tumucumaque and BRS Imponente cultivars.

Table 4. Means of dry seed yield and seed index of 14 cowpea (Vigna unguiculata) genotypes, in the 2016, 2017, and 2018 crop years, in the municipality of Rio Branco, in the state of Acre, Brazil ${ }^{(1)}$.

\begin{tabular}{|c|c|c|c|c|c|c|c|}
\hline \multirow[t]{2}{*}{ Genotype $^{(2)}$} & \multicolumn{3}{|c|}{ Dry seed yield $\left(\mathrm{kg} \mathrm{ha}^{-1}\right)$} & \multicolumn{3}{|c|}{ Seed index $(\%)$} & \multirow[t]{2}{*}{ Mean } \\
\hline & 2016 & 2017 & 2018 & 2016 & 2017 & 2018 & \\
\hline BDO 1-5-11 & $1192.00 \mathrm{aA}$ & $1063.60 \mathrm{aA}$ & $1147.95 \mathrm{aA}$ & 76.78 & 78.20 & 78.57 & $77.85 \mathrm{a}$ \\
\hline BDO 1-5-15 & $1385.75 \mathrm{aA}$ & $1357.45 \mathrm{aA}$ & $1157.15 \mathrm{aA}$ & 73.36 & 83.91 & 78.91 & $78.73 a$ \\
\hline BDO 1-5-19 & $1113.00 \mathrm{aA}$ & $1187.00 \mathrm{aA}$ & $1138.87 \mathrm{aA}$ & 65.51 & 77.54 & 82.18 & $75.08 \mathrm{a}$ \\
\hline BDO 1-5-24 & $1243.40 \mathrm{aA}$ & $1233.45 \mathrm{aA}$ & $1114.27 \mathrm{aA}$ & 80.90 & 79.67 & 73.52 & $78.03 \mathrm{a}$ \\
\hline $\mathrm{PDO}^{2} 1-5-26$ & $1523.00 \mathrm{aA}$ & $1276.85 \mathrm{aAB}$ & $1096.40 \mathrm{aB}$ & 80.15 & 84.11 & 79.89 & $81.38 \mathrm{a}$ \\
\hline PDO 1-5-4 & $1297.00 \mathrm{aA}$ & $1225.60 \mathrm{aA}$ & $1157.60 \mathrm{aA}$ & 76.01 & 82.77 & 81.77 & $80.56 \mathrm{a}$ \\
\hline PDO 1-5-5 & $1377.00 \mathrm{aA}$ & $1160.60 \mathrm{aA}$ & $1156.07 \mathrm{aA}$ & 80.86 & 80.04 & 82.71 & $81.20 \mathrm{a}$ \\
\hline PDO 1-5-7 & $1401.75 \mathrm{aA}$ & $1030.40 \mathrm{aB}$ & $1164.05 \mathrm{aAB}$ & 81.98 & 78.74 & 76.87 & $79.20 \mathrm{a}$ \\
\hline PDO 1-5-8 & $1484.25 \mathrm{aA}$ & $1089.95 \mathrm{aB}$ & $1093.12 \mathrm{aB}$ & 82.59 & 72.17 & 78.84 & $77.87 \mathrm{a}$ \\
\hline PDO 1-5-10 & $1338.67 \mathrm{aA}$ & $1349.30 \mathrm{aA}$ & $1162.00 \mathrm{aA}$ & 85.11 & 86.35 & 79.92 & $83.67 \mathrm{a}$ \\
\hline PDO 1-5-11 & $975.00 \mathrm{aA}$ & $1078.00 \mathrm{aA}$ & $1145.80 \mathrm{aA}$ & 86.67 & 81.32 & 76.37 & $79.71 \mathrm{a}$ \\
\hline PDO 1-5-14 & $1146.50 \mathrm{aA}$ & $1228.90 \mathrm{aA}$ & $1134.82 \mathrm{aA}$ & 75.94 & 84.43 & 61.96 & $74.11 \mathrm{a}$ \\
\hline BRS Tumucumaque & $1287.95 \mathrm{aA}$ & $720.25 \mathrm{aB}$ & $1112.47 \mathrm{aA}$ & 90.92 & 78.50 & 79.00 & $76.14 \mathrm{a}$ \\
\hline BRS Imponente & $1186.75 \mathrm{aA}$ & $946.55 \mathrm{aA}$ & $1148.80 \mathrm{aA}$ & 79.18 & 75.10 & 88.31 & $80.86 \mathrm{a}$ \\
\hline Mean & - & - & - & $77.70 \mathrm{~A}$ & $80.20 \mathrm{~A}$ & $78.79 \mathrm{~A}$ & - \\
\hline
\end{tabular}

(1)Means followed by equal letters, uppercases in the rows, and lowercases in the columns, do not differ by the Tukey's and the Scott-Knott's tests, at 5\% probability each.(2)BDO, "Bico-de-Ouro" lines; PDO, "Pingo-de-Ouro" lines; and BRS Tumucumaque and BRS Imponente cultivars. 
the genetic response of the genotype to environmental variation.

The SID, which indicates the efficiency of each genotype in the grain production (Silva et al., 2018), showed no significant difference in the $G \times \mathrm{Y}$ interaction and in the means; however, values varying from $75.08 \%$ (BDO 1-5-19) to $83.77 \%$ (RFQ 1-5-10) were recorded (Table 4).

Sousa et al. (2015) evaluated different cowpea genotypes and found means of $62 \%$ and $64 \%$ for the trait SID. Silva et al. (2018) reported means of 73.02\% in 2014, and $86.33 \%$ in 2015; and Públio Júnior et al. (2017) recorded an overall mean of $78 \%$. Therefore, the means found in the present study for this trait can be considered adequate and suggest a good efficiency in grain production (Table 4), similarly to the results for agronomic performance of cowpea in two crop years reported by Silva et al. (2018).

The PGH in most genotypes varied from erect to semi-erect in all crop years, with means varying from 1 (erect plant) to 2 (semi-erect plant) (Table 5). The PDO 1-5-26, PDO 1-5-5, PDO 1-5-8, and PDO 1-5-11 lines, and the BRS Tumucumaque cultivar had PGH tending to semiprostrate in the first and second crop years, 2016 and 2017, respectively. However, in 2018, all genotypes varied from erect to semi-erect (Table 5). Farmers who aim to use mechanized agriculture prefer plants with growth tending to erect growth.
The criteria for the cultivation value include the general aspect of the plants, vigor, pod distribution, seed commercial characteristics, and resistance to diseases and pests of the genotypes. For cowpea genotypes, those considered acceptable should score 3 or above (Silva et al., 2018). In the present work, the BDO 1-5-11, BDO 1-5-15, BDO 1-5-24, and PDO 1-5-4 lines, and the BRS Imponente cultivar showed a tendency for a good deal of the characteristics suitable for commercial cultivation in the three crop years.

Most genotypes showed good LOD resistance, with means ranging from 1 (with no lodged plant or main branch unbroken) to 2 (with 1 to $5 \%$ lodged plants or main branch broken) (Table 5). The PDO 1-5-4 and PDO 1-5-10 lines, in 2016, and PDO 1-5-5, in 2017, showed from $6 \%$ to $10 \%$ lodged plants or with the main branch broken (scored 3). According to Guerra et al. (2017), farmers prefer erect plants with a low LOD degree, since they allow of mechanization in the area.

BRS Tumucumaque and BRS Imponente cultivars, in addition to their good production performance, have white grain teguments, which is a characteristic predominantly accepted by cowpea consumers in Acre state. The results show that the tested genotypes have favorable characteristics for the selection for cultivation and incorporation into the production system of Rio Branco, Acre state, Brazil.

Table 5. Means of growth habit, cultivation value, and lodging of 14 cowpea (Vigna unguiculata) genotypes, in the 2016, 2017, and 2018 crop years, in the municipality of Rio Branco, in the state of Acre, Brazil ${ }^{(1)}$.

\begin{tabular}{|c|c|c|c|c|c|c|c|c|c|}
\hline \multirow[t]{2}{*}{ Genotype $^{(2)}$} & \multicolumn{3}{|c|}{ Growth habit } & \multicolumn{3}{|c|}{ Value of cultivation } & \multicolumn{3}{|c|}{ Lodging } \\
\hline & 2016 & 2017 & 2018 & 2016 & 2017 & 2018 & 2016 & 2017 & 2018 \\
\hline BDO 1-5-11 & $1.50 \mathrm{bA}$ & $1.50 \mathrm{bA}$ & $2.00 \mathrm{aA}$ & $3.25 \mathrm{aA}$ & $3.25 \mathrm{bA}$ & $3.00 \mathrm{aA}$ & $1.50 \mathrm{aA}$ & $1.75 \mathrm{aA}$ & $2.12 \mathrm{aA}$ \\
\hline BDO 1-5-15 & $1.25 \mathrm{bA}$ & $1.50 \mathrm{bA}$ & $2.00 \mathrm{aA}$ & $3.50 \mathrm{aA}$ & $4.00 \mathrm{aA}$ & $3.00 \mathrm{aA}$ & $2.00 \mathrm{aA}$ & $2.25 \mathrm{aA}$ & $2.25 \mathrm{aA}$ \\
\hline BDO 1-5-19 & $1.50 \mathrm{bA}$ & $1.50 \mathrm{bA}$ & $2.50 \mathrm{aA}$ & $4.00 \mathrm{aA}$ & $4.25 \mathrm{aA}$ & $2.50 \mathrm{aB}$ & $1.25 \mathrm{aA}$ & $1.50 \mathrm{aA}$ & $2.37 \mathrm{aA}$ \\
\hline BDO 1-5-24 & $1.75 \mathrm{bA}$ & $1.75 \mathrm{bA}$ & $1.87 \mathrm{aA}$ & $3.50 \mathrm{aAB}$ & $4.25 \mathrm{aA}$ & $3.00 \mathrm{aB}$ & $1.75 \mathrm{aA}$ & $2.00 \mathrm{aA}$ & $2.12 \mathrm{aA}$ \\
\hline PDO 1-5-26 & $2.50 \mathrm{aAB}$ & $3.00 \mathrm{aA}$ & $1.50 \mathrm{aB}$ & $3.75 \mathrm{aA}$ & $2.00 \mathrm{bB}$ & $3.00 \mathrm{aA}$ & $1.25 \mathrm{aA}$ & $1.75 \mathrm{aA}$ & $2.00 \mathrm{aA}$ \\
\hline PDO 1-5-4 & $1.00 \mathrm{bA}$ & $1.25 \mathrm{bA}$ & $2.00 \mathrm{aA}$ & $3.66 \mathrm{aA}$ & $3.75 \mathrm{aA}$ & $3.00 \mathrm{aA}$ & $3.33 \mathrm{aA}$ & $2.00 \mathrm{aB}$ & $1.75 \mathrm{aB}$ \\
\hline PDO 1-5-5 & $2.75 \mathrm{aA}$ & $2.75 \mathrm{aA}$ & $1.75 \mathrm{aA}$ & $2.50 \mathrm{aA}$ & $2.00 \mathrm{bA}$ & $3.00 \mathrm{aA}$ & $2.25 \mathrm{aAB}$ & $3.50 \mathrm{aA}$ & $1.87 \mathrm{aB}$ \\
\hline PDO 1-5-7 & $1.75 \mathrm{bA}$ & $1.75 \mathrm{bA}$ & $1.87 \mathrm{aA}$ & $3.25 \mathrm{aAB}$ & $4.00 \mathrm{aA}$ & $2.75 \mathrm{aB}$ & $2.00 \mathrm{aA}$ & $2.00 \mathrm{aA}$ & $1.62 \mathrm{aA}$ \\
\hline PDO 1-5-8 & $2.50 \mathrm{aA}$ & $2.50 \mathrm{aA}$ & $2.12 \mathrm{aA}$ & $2.75 \mathrm{aA}$ & $2.25 \mathrm{bA}$ & $2.75 \mathrm{aA}$ & $1.75 \mathrm{aA}$ & $2.25 \mathrm{aA}$ & $1.75 \mathrm{aA}$ \\
\hline PDO 1-5-10 & $2.00 \mathrm{bA}$ & $2.25 \mathrm{aA}$ & $1.62 \mathrm{aA}$ & $2.66 \mathrm{aA}$ & $2.75 \mathrm{bA}$ & $3.50 \mathrm{aA}$ & $3.33 \mathrm{aA}$ & $2.50 \mathrm{aA}$ & $1.12 \mathrm{aB}$ \\
\hline PDO 1-5-11 & $3.00 \mathrm{aA}$ & $2.00 \mathrm{bA}$ & $1.87 \mathrm{aA}$ & $2.00 \mathrm{aA}$ & $2.25 \mathrm{bA}$ & $3.50 \mathrm{aA}$ & $1.00 \mathrm{aA}$ & $2.25 \mathrm{aA}$ & $1.75 \mathrm{aA}$ \\
\hline PDO 1-5-14 & $1.75 \mathrm{bA}$ & $2.00 \mathrm{bA}$ & $1.75 \mathrm{aA}$ & $2.50 \mathrm{aA}$ & $2.75 \mathrm{bA}$ & $3.12 \mathrm{aA}$ & $2.25 \mathrm{aA}$ & $2.25 \mathrm{aA}$ & $1.62 \mathrm{aA}$ \\
\hline BRS Tumucumaque & $2.75 \mathrm{aA}$ & $2.50 \mathrm{aA}$ & $2.25 \mathrm{aA}$ & $2.25 \mathrm{aB}$ & $2.75 \mathrm{bAB}$ & $3.62 \mathrm{aA}$ & $2.75 \mathrm{aA}$ & $2.00 \mathrm{aAB}$ & $1.25 \mathrm{aB}$ \\
\hline BRS Imponente & $1.00 \mathrm{bA}$ & $1.00 \mathrm{bA}$ & $2.00 \mathrm{aA}$ & $2.75 \mathrm{aA}$ & $3.00 \mathrm{bA}$ & $3.37 \mathrm{aA}$ & $1.00 \mathrm{aA}$ & $1.00 \mathrm{aA}$ & $1.37 \mathrm{aA}$ \\
\hline
\end{tabular}

(1) Means followed by equal letters, uppercases in the rows and lowercases letters in the columns, do not differ by the Tukey's and the Scott-Knott's tests, at $5 \%$ probability each. ${ }^{(2)} \mathrm{BDO}$, "Bico-de-Ouro" lines; PDO, "Pingo-de-Ouro" lines; and BRS Tumucumaque and BRS Imponente cultivars. 


\section{Conclusion}

The evaluated cowpea (Vigna unguiculata) lines and the BRS Tumucumaque and BRS Imponente cultivars show equivalent and favorable agronomic performances in the environmental conditions of the municipality of Rio Branco, in the southwestern Brazilian Amazon, and, therefore, these genotypes can be selected for incorporation into the production system of the region.

\section{References}

ACOMPANHAMENTO DA SAFRA BRASILEIRA [DE] GRÃOS: safra 2020/21: segundo levantamento, v.8, n.2, nov. 2020. Available at: <https://www.conab.gov.br/info-agro/safras/ graos/boletim-da-safra-de-graos>. Accessed on: Nov. 172020.

AGRITEMPO. Sistema de Monitoramento Agrometeorológico. Available at: <https://www.agritempo.gov.br/agritempo/jsp/ Estatisticas/index.jsp?siglaUF=AC $>$. Accessed on: Dec. 212020.

ANDRADE JÚNIOR, A.S. de; BASTOS, E.A.; CARDOSO, M.J. Clima. In: BASTOS, E.A. (Ed.). Cultivo de feijão-caupi. 2.ed. Brasília: Embrapa, 2017. Versão eletrônica. (Embrapa MeioNorte. Sistema de produção, 2; Embrapa Amazônia Ocidental. Sistema de produção, 2; Embrapa Agrobiologia. Sistema de produção, 4).

ARAÚJO, L.B.R.; PINHEIRO, M. de S.; FIEGE, L.B. da C.; BERTINI, C.H.C. de M.; DOVALE, J.C. Agronomic potential and genetic diversity of landraces of cowpea of the state of Ceará. Revista Caatinga, v.32, p.698-708, 2019. DOI: https://doi.org/10.1590/1983-21252019v32n314rc.

BANZATTO, D.A.; KRONKA, S. do N. Experimentação Agrícola. 4.ed. Jaboticabal: FUNEP, 2006. 237p.

CAMARA, F.T. da; MOTA, A.M.D.; NICOLAU, F.E. de A.; PINTO, A.A.; SILVA, J.M.F. de. Produtividade de feijão caupi crioulo em função do espaçamento entre linhas e número de plantas por cova. Revista de Agricultura Neotropical, v.5, p.1924, 2018. DOI: https://doi.org/10.32404/rean.v5i2.2282.

CAVALCANTE, E. da S.; FREIRE FILHO, F.R.; ROCHA, M. de M.; GÓES, A.C.P.; RIBEIRO, V.Q.; SILVA, K.J.D. e. BRS Tumucumaque: cultivar de feijão-caupi para o Amapá e outros estados do Brasil. Macapá: Embrapa Amapá, 2014. 5p. (Embrapa Amapá. Comunicado técnico, 124).

DUTRA A.S.; BEZERRA F.T.C.; NASCIMENTO P.R.; LIMA D. de C. Produtividade e qualidade fisiológica de sementes de feijão caupi em função da adubação nitrogenada. Revista Ciência Agronômica, v.43, p.816-821, 2012. DOI: https://doi.org/10.1590/ s1806-66902012000400025.

FAO. Food and Agriculture Organization of the United Nations. Faostat. Available at: <http://www.fao.org/faostat/en/\#data/QC $>$. Accessed on: Sept. 302019.
FERREIRA, D.F. Sisvar: a guide for its bootstrap procedures in multiple comparisons. Ciência e Agrotecnologia, v.38, p.109-112, 2014. DOI: https://doi.org/10.1590/S1413-70542014000200001.

FREIRE FILHO, F.R. (Ed.). Feijão-caupi no Brasil: produção, melhoramento genético, avanços e desafios. Teresina: Embrapa Meio-Norte, 2011. 84p.

GUERRA, J.V.S.; CARVALHO, A.J. de; MEDEIROS, J.C.; SOUZA, A.A. de; BRITO, O.G. Agronomic performance of erect and semi-erect cowpea genotypes in the north of Minas Gerais, Brazil. Revista Caatinga, v.30, p.679-686, 2017. DOI: https://doi.org/10.1590/1983-21252017v30n316rc.

LOCATELLI, V. da E.R.; MEDEIROS, R.D. de; SMIDERLE, O.J.; ALBUQUERQUE, J. de A.A. de; ARAÚJO, W.F.; SOUZA, K.T.S. de. Componentes de produção, produtividade e eficiência da irrigação do feijão-caupi no Cerrado de Roraima. Revista Brasileira de Engenharia Agrícola e Ambiental, v.18, p.574-580, 2014. DOI: https://doi.org/10.1590/S1415-43662014000600002.

LOPES, A. da S.; OLIVEIRA, G.Q. de; SOUTO FILHO, S.N.; GOES, R.J.; CAMACHO, M.A.C. Manejo de irrigação e nitrogênio no feijoeiro comum cultivado em sistema de plantio direto. Revista Ciência Agronômica, v.42, p.51-56, 2011. DOI: https://doi.org/10.1590/S1806-66902011000100007.

LOPES, L.M; SOUSA, A.H.; SANTOS, V.B.; SILVA, G.N.; ABREU, A.O. Development rates of Callosobruchus maculatus (Coleoptera: Chrysomelidae) in landrace cowpea varieties occurring in southwestern Amazonia. Journal of Stored Products Research, v.76, p.111-115, 2018. DOI: https://doi.org/10.1016/j.jspr.2018.01.008.

MATOS FILHO, C.H.A.; GOMES, R.L.F.; ROCHA, M.M.; FREIRE FILHO, F.R.; LOPES, A.C. de A. Potencial produtivo de progênies de feijão-caupi com arquitetura ereta de planta. Ciência Rural, v.39, p.348-354, 2009. DOI: https://doi.org/10.1590/S010384782009000200006 .

MEDEIROS, R.D. de; QUEIROZ, F.B.D. de; QUEIROZ, R.D.D. de. Produtividade e eficiência de uso da água de cultivares de feijão-caupi no Cerrado em Roraima. Boa Vista: Embrapa Roraima, 2017. 11p. (Embrapa Roraima. Documentos, 63). Available at: <https://ainfo.cnptia.embrapa.br/digital/bitstream/ item/184166/1/NOVO-DOC-N-631.pdf $>$. Accessed on: Feb. 10 2020 .

MELO, F. de B.; CARDOSO, M.J. Solos e adubação. In: BASTOS, E.A. (Ed.). Cultivo de feijão-caupi. 2.ed. Brasília: Embrapa, 2017. Versão eletrônica. (Embrapa Meio-Norte. Sistema de produção, 2; Embrapa Amazônia Ocidental. Sistema de produção, 2; Embrapa Agrobiologia. Sistema de produção, 4).

MENDONÇA, M.S. de; BEBER, P.M.; NASCIMENTO, F.S.S. do; SANTOS, V.B. dos; MARINHO, J.T. Importance and correlations of characters for cowpea diversity in traditional varieties. Revista Ciência Agronômica, v.49, p.267-274, 2018. DOI: https://doi.org/10.5935/1806-6690.20180030.

OLIVEIRA, E. de; MATTAR, E.P.L.; ARAÚJO, M.L. de; JESUS, J.C.S. de; NAGY, A.C.G.; SANTOS, V.B. dos. Descrição de cultivares locais de feijão-caupi coletados na microrregião de Cruzeiro do Sul, Acre, Brasil. Acta Amazonica, v.45, p.243-254, 2015. DOI: https://doi.org/10.1590/1809-4392201404553. 
PINTO, A.A.; CAMARA, F.T. da; SIVA, F.E. da; SANTANA, L.D.; RODRIGUES, W.A.D. Espaçamento longitudinal e produtividade de feijão caupi com uso de semeadora manual. Revista Engenharia na Agricultura, v.25, p.500-508, 2017. DOI: https://doi.org/10.13083/reveng.v25i6.750.

PÚBLIO JÚNIOR, E.; MORAIS, O.M.; ROCHA, M. de M.; PÚBLIO, A.P.P.B.; BANDEIRA, A. da S. Características agronômicas de genótipos de feijão-caupi cultivados no sudoeste da Bahia. Científica: Revista de Ciências Agrárias, v.45, p.223-230, 2017. DOI: https://doi.org/10.15361/19845529.2017v45n3p223-230.

ROCHA, M. de M.; SILVA, K.J.D.; FREIRE FILHO, F.R.; MENEZES JUNIOR, J.A.N. de. Cultivares. In: BASTOS, E.A. (Ed.). Cultivo de Feijão-caupi. 2.ed. Brasília: Embrapa, 2017. Versão eletrônica. (Embrapa Meio-Norte. Sistema de produção, 2; Embrapa Amazônia Ocidental. Sistema de produção, 2; Embrapa Agrobiologia. Sistema de produção, 4). Available at: <https:// www.spo.cnptia.embrapa.br/conteudo?p_p_id=conteudoportlet_ WAR_sistemasdeproducaolf6_1galceportlet\&p_p_ lifecycle $=0 \& p \_p \_s t a t e=$ normal\&p_p_mode $=$ view\&p_p_col_ $\mathrm{id}=$ column-1\&p_p_col_count $=1 \& p \_r$ _p_-76293187_sistemaProd ucaoId=9109\&p_r_p_-996514994_topicoId $=1307>$. Accessed on: Dec. 212020.

SANTOS, H.G. dos; JACOMINE, P.K.T.; ANJOS, L.H.C. dos; OLIVEIRA, V.Á. de; LUMBRERAS, J.F.; COELHO, M.R.; ALMEIDA, J.A. de; ARAÚJO FILHO, J.C. de; OLIVEIRA, J.B. de; CUNHA, T.J.F. Sistema brasileiro de classificação de solos. 5.ed. rev. e ampl. Brasília: Embrapa, 2018. Available at: $<$ https:// www.embrapa.br/solos/sibcs>. Accessed on: Nov. 132020.

SILVA, G.C.; MAGALHÃES, R.C.; SOBREIRA, A.C.; SCHMITZ, R.; SILVA, L.C. da. Rendimento de grãos secos e componentes de produção de genótipos de feijão-caupi em cultivo irrigado e de sequeiro. Revista Agro@mbiente On-line, v.10, p.342-350, 2016. DOI: https://doi.org/10.18227/1982-8470ragro. v10i4.3385.

SILVA, M.B. de O.; CARVALHO, A.J. de; ROCHA, M. de M.; BATISTA, P.S.C.; SANTOS JÚNIOR, P.V.; OLIVEIRA, S.M. de. Desempenho agronómico de genótipos de feijão-caupi. Revista de Ciências Agrárias, v.41, p.1059-1066, 2018. DOI: http://doi.org/10.19084/RCA17309.

SOUSA, J.L.M.; ROCHA, M. de M.; SILVA, K.J.D. e; NEVES, A.C. das; SOUSA, R.R. de. Potencial de genótipos de feijão-caupi para o mercado de vagens e grãos verdes. Pesquisa Agropecuária Brasileira, v.50, p.392-398, 2015. DOI: https://doi.org/10.1590/ S0100-204X2015000500006.

SOUZA, V.B. de; CARVALHO, A.J. de; DAMASCENOSILVA, K.J.; ROCHA, M. de M.; LACERDA, M.L.; PEREIRA FILHO, I.A. Agronomic performance of cowpea elite lines in the states of Minas Gerais and Mato Grosso, Brazil. Revista Caatinga, v.31, p.90-98, 2018. DOI: https://doi.org/10.1590/198321252018v31n111rc.

TEIXEIRA, I.R.; SILVA, G.C. da; OLIVEIRA, J.P.R. de; SILVA, A.G. da; PELÁ, A. Desempenho agronômico e qualidade de sementes de cultivares de feijão-caupi na região do cerrado. Revista Ciência Agronômica, v.41, p.300-307, 2010. DOI: https://doi.org/10.1590/S1806-66902010000200019.

TORRES, F.E.; SAGRILO, E.; TEODORO, P.E.; RIBEIRO, L.P.; CARGNELUTTI FILHO, A. Número de repetições para avaliação de caracteres em genótipos de feijão-caupi. Bragantia, v.74, p.161168, 2015. DOI: https://doi.org/10.1590/1678-4499.0393.

VALERIANO, T.T.B.; BORGES, R. de M.; ALMEIDA, F. da S.; SILVA NETO, O.F. da; SANTANA, M.J. de; SILVA, K.A. Desempenho agronômico de cultivares de feijão-caupi em função da densidade de plantas. Revista Inova Ciência \& Tecnologia, v.5, p.12-17, 2019. 